\title{
Lifelong challenge of calcium homeostasis in male mice lacking TRPV5 leads to changes in bone and calcium metabolism
}

\author{
Bram C.J. van der Eerden ${ }^{1, *}$, W. Nadia H. Koek ${ }^{1, *}$, Paul Roschger ${ }^{2}$, M. Carola \\ Zillikens', Jan H. Waarsing ${ }^{3}$, Annemiete van der Kemp ${ }^{4}$, Marijke Schreuders- \\ Koedam $^{1}$, Nadja Fratzl-Zelman ${ }^{2}$, Pieter J.M. Leenen ${ }^{5}$, Joost G.J. Hoenderop ${ }^{4}$, Klaus \\ Klaushofer ${ }^{2}$, René J.M. Bindels ${ }^{4}$ and Johannes P.T.M. van Leeuwen ${ }^{1}$ \\ ${ }^{1}$ Department of Internal Medicine, Erasmus MC, Rotterdam, The Netherlands \\ 2 Ludwig Boltzman Institute of Osteology at Hanusch Hospital of WGKK and AUVA Trauma Centre Meidling, 1st Medical \\ Department, Hanusch Hospital, Vienna, Austria \\ 3 Department of Orthopedics, Erasmus MC, Rotterdam, The Netherlands \\ ${ }^{4}$ Department of Physiology, Nijmegen Centre for Molecular Life Sciences, Radboud University Nijmegen Medical Centre, The \\ Netherlands \\ ${ }^{5}$ Department of Immunology, Erasmus MC, Rotterdam, The Netherlands \\ * These authors have contributed equally to this paper \\ Correspondence to: Bram C. J. van der Eerden, email: b.vandereerden@erasmusmc.nl
}

Keywords: TRPV5, bone resorption, mineralization, calcium homeostasis, aging, Gerotarget

Received: January 05, $2016 \quad$ Accepted: March 31, $2016 \quad$ Published: April 18, 2016

\section{ABSTRACT}

Trpv5 plays an important role in calcium $\left(\mathrm{Ca}^{2+}\right)$ homeostasis, among others by mediating renal calcium reabsorption. Accordingly, Trpv5 deficiency strongly stresses $\mathrm{Ca}^{2+}$ homeostasis in order to maintain stable serum $\mathrm{Ca}^{2+}$. We addressed the impact of lifelong challenge of calcium homeostasis on the bone phenotype of these mice.

Aging significantly increased serum 1,25(OH $)_{2} D_{3}$ and PTH levels in both genotypes but they were more elevated in $\mathrm{Trpv5}^{-/-}$mice, whereas serum $\mathrm{Ca}^{2+}$ was not affected by age or genotype. Age-related changes in trabecular and cortical bone mass were accelerated in Trpv5 $5^{-/-}$mice, including reduced trabecular and cortical bone thickness as well as reduced bone mineralization. No effect of Trpv5 deficiency on bone strength was observed. In 78-week-old mice no differences were observed between the genotypes regarding urinary deoxypyridinoline, osteoclast number, differentiation and activity as well as osteoclast precursor numbers, as assessed by flow cytometry.

In conclusion, life-long challenge of $\mathrm{Ca}^{2+}$ homeostasis present in $\mathrm{Trpv5} /-$ mice causes accelerated bone aging and a low cortical and trabecular bone mass phenotype. The phenotype of the Trpv5 $5^{-/-}$mice suggests that maintenance of adequate circulatory $\mathrm{Ca}^{2+}$ levels in patients with disturbances in $\mathrm{Ca}^{2+}$ homeostasis should be a priority in order to prevent bone loss at older age.

\section{INTRODUCTION}

Maintenance of adequate $\mathrm{Ca}^{2+}$ levels is of crucial importance for many physiological processes in the body including neuronal excitability, muscle contraction and bone formation. Bone is the major site of $\mathrm{Ca}^{2+}$ storage in the body, and formation and mineralization by osteoblasts as well as osteoclastic bone resorption, contribute to the maintenance of $\mathrm{Ca}^{2+}$ equilibrium in the circulation. Serum $\mathrm{Ca}^{2+}$ is tightly regulated through the concerted interactions of kidneys, intestines and bone. Transcellular $\mathrm{Ca}^{2+}$ (re) absorption is an important process in maintaining $\mathrm{Ca}^{2+}$ balance by these tissues [1,2].

Previously, we published on the phenotype of mice lacking the epithelial $\mathrm{Ca}^{2+}$ channel Trpv5 (Trpv5 $\left.5^{-}\right)$[3]. TRPV5 is a $\mathrm{Ca}^{2+}$-selective transient receptor potential 
Table 1: Serum measurements in $\operatorname{Trpv}^{+/+}$and $\operatorname{Trpv}^{+/+}$mice during aging

\begin{tabular}{|c|c|c|c|c|c|c|}
\hline & \multicolumn{2}{|c|}{10 weeks } & \multicolumn{2}{|c|}{52 weeks } & \multicolumn{2}{|c|}{78 weeks } \\
\hline & $\begin{array}{c}\text { Trpv }^{+/+} \\
\text {mean } \pm \text { sem } \\
n=5\end{array}$ & $\begin{array}{c}\text { Trpv5 }^{-/-} \\
\text {mean } \pm \text { sem } \\
n=5\end{array}$ & $\begin{array}{c}\text { Trpv }^{+/+} \\
\text {mean } \pm \text { sem } \\
n=5\end{array}$ & $\begin{array}{c}\text { Trpv }^{-/-} \\
\text {mean } \pm \text { sem } \\
n=3\end{array}$ & $\begin{array}{c}\text { Trpv }^{+/+} \\
\text {mean } \pm \text { sem } \\
n=4\end{array}$ & $\begin{array}{c}\text { Trpv }^{-\alpha-} \\
\text { mean } \pm \text { sem } \\
n=5\end{array}$ \\
\hline \multicolumn{7}{|l|}{ Serum } \\
\hline Calcium (mmol/ll) * \# & $2.76 \pm 0.02$ & $2.84 \pm 0.02$ & $2.71 \pm 0.04$ & $2.79 \pm 0.04$ & $2.02 \pm 0.27$ & $1.70 \pm 0.29$ \\
\hline $1,25(\mathrm{OH})_{2} \mathrm{D}_{3}(\mathrm{pmol} / \mathrm{l})$ & $121 \pm 24$ & $686 \pm 77^{b}$ & $542 \pm 41$ & $518 \pm 108$ & $474 \pm 50^{c}$ & $1321 \pm 133^{b, d}$ \\
\hline Parathyroid hormone $(\mathrm{pg} / \mathrm{ml})^{\#}$ & $9.9 \pm 1.9$ & $22.6 \pm 6.0$ & $30.7 \pm 6.2$ & $100 \pm 20.6^{a}$ & $84.8 \pm 21.9^{c}$ & $60.2 \pm 18.1$ \\
\hline \multicolumn{7}{|c|}{$\begin{array}{l}{ }^{a} \mathrm{p}<0.05 \mathrm{vs} \operatorname{Trpv} 5^{+/+} \text {mice of same age }{ }^{b} \mathrm{p}<0.001 \mathrm{vs} \operatorname{Trpv} 5^{+/+} \text {mice of same age }{ }^{c} \mathrm{P}<0.05 \text { for age trend in } \operatorname{Trpv} 5^{+/+} \text {mice. }{ }^{d} p<0.05 \text { for } \\
\text { age trend in Trpv } 5^{-/-} \text {mice. }\end{array}$} \\
\hline \multicolumn{7}{|c|}{ *Levels at 78 weeks of age were measured by different assay compared to 10 and 52 weeks } \\
\hline \multicolumn{7}{|c|}{ \#Published previously by Abel et al.[1] } \\
\hline $\begin{array}{l}\text { 1. van Abel, M., et al., } A \\
\text { 2006. 291(6): p. F117 }\end{array}$ & alterations in & a2+ homeost & sis: role of $T h$ & PV5 and TRF & Am J Physio & enal Physiol, \\
\hline
\end{tabular}

channel that is expressed in renal epithelial cells and crucial for reabsorption of calcium. In $\operatorname{Trp} v 5^{-/}$mice, besides hypercalciuria, intestinal $\mathrm{Ca}^{2+}$ hyperabsorption takes place by upregulation of the close homolog of Trpv5, Trpv6. This process is impaired when $1,25(\mathrm{OH})_{2} \mathrm{D}_{3}$ bioactivity is disturbed as shown in double knockout mice for TRPV5 and $1 \alpha$-hydroxylase (synthesizes $1,25(\mathrm{OH})_{2} \mathrm{D}_{3}$ ) and by treatment of $\operatorname{Trp} v 5^{-/}$mice with a vitamin $\mathrm{D}$ receptor antagonist, ZK191784 [4, 5].

A detailed study on bone in these mice revealed that Trpv5 has a direct role in bone [6]. Trpv5 $5^{--}$mice display an aberrant bone phenotype, including reduced cortical and trabecular bone thickness. Within bone, TRPV5 appears to be expressed by osteoclasts exclusively at the site where bone resorption takes place. Despite enhanced osteoclastogenesis, both in vivo and in vitro, bone resorption is seriously disturbed in mice lacking Trpv5, indicating that TRPV5 is required for proper osteoclast function.

It is known that increasing age is accompanied by changes in $\mathrm{Ca}^{2+}$ homeostasis, including reduced $\mathrm{Ca}^{2+}$ absorption from the diet, reduced vitamin D availability, which predisposes older persons to disorders related to $\mathrm{Ca}^{2+}$ homeostasis, particularly secondary hyperparathyroidism and osteoporosis $[7,8]$. In addition, the capacity of $1,25(\mathrm{OH})_{2} \mathrm{D}_{3}$ to stimulate intestinal $\mathrm{Ca}^{2+}$ absorption declines with age, whereas circulating levels of PTH rise with age in rats and humans $[9,10]$. Moreover, age-related increase in PTH levels may play an important role in changes in bone remodeling. Bone loss occurs universally with aging, leading to a reduction in bone mass and strength eventually leading to bone fragility and increased risk of osteoporotic fractures in the elderly [7, $11]$.

We previously demonstrated that compared to wildtype $\left(\operatorname{Trp} v 5^{+/+}\right)$mice, both renal $\mathrm{Ca}^{2+}$ reabsorption and intestinal $\mathrm{Ca}^{2+}$ absorption were reduced during aging in Trpv5 $5^{-1}$ mice, of which the latter was associated with
Trpv6 expression [12]. Moreover, elevated vitamin D receptor protein levels observed in the intestine in older mice are indicative for vitamin $\mathrm{D}$ resistance.

In this study we aimed to investigate the bone phenotype of aging $\operatorname{Trp} v 5^{+/+}$and Trpv5 $5^{-/}$mice by detailed analyses of serum and urine parameters related to calcium homeostasis and bone resorption, bone microarchitecture, mineralization and strength in vivo. Moreover, bone marrow cultures from long bones were performed to assess osteoblast and osteoclast differentiation in 78-weekold $\operatorname{Tr} p v 5^{+/+}$and $\operatorname{Tr} p v 5^{-/}$mice. Finally, the impact of aging on calcium homeostasis and bone-related gene expression was examined in femurs and bone marrow cultures from both genotypes.

\section{RESULTS}

\section{Serum 1,25(OH) $)_{3}$ and PTH are age-dependently elevated in $\operatorname{Trpv5}^{-/-}$mice}

No difference in serum $\mathrm{Ca}^{2+}$ levels were observed between $\operatorname{Tr} p v 5^{+/+}$and $\operatorname{Tr} p v 5^{-/-}$mice at all three ages (Table 1). Serum $\mathrm{Ca}^{2+}$ in the oldest age group (78 weeks) was measured with a different calcium assay, which hampers direct comparison between the younger 2 age cohorts with the 78-week-old mice. However, using the same assay, previous measurements in an aging cohort of wild type mice up to 2 years of age yielded similar $\mathrm{Ca}^{2+}$ levels compared to the 78-week-old mice in this study (Supplementary Table 2). In Trpv5 $5^{+/+}$mice, $1,25(\mathrm{OH})_{2} \mathrm{D}_{3}$ $(\mathrm{pmol} / \mathrm{l})$ and PTH $(\mathrm{pg} / \mathrm{ml})$ levels increased significantly with aging (Figure 1 and Table 1). In $\operatorname{Tr} v v 5^{-/}$mice a similar age-related increase in serum $1,25(\mathrm{OH})_{2} \mathrm{D}_{3}$ was observed but serum $1,25(\mathrm{OH})_{2} \mathrm{D}_{3}$ levels were significantly higher in Trpv5 $5^{-/}$compared to their Trpv5 $5^{+/+}$littermates at 10 and 78 weeks of age. PTH level in $\operatorname{Trp} v 5^{-/}$mice increased 
with age but was only significantly higher at 52 weeks age compared to $\operatorname{Tr} p v 5^{+/+}$mice. In 10-week-old $\operatorname{Tr} p v 5^{-/-}$ mice, both PTH and $1,25(\mathrm{OH})_{2} \mathrm{D}_{3}$ were at a level that is not reached before 52 weeks of age in Trpv $5^{+/+}$littermates (Figure 1 and Table 1).

\section{Trabecular and cortical bone mass are reduced in TRPV5 ${ }^{-/-}$mice}

In $T r p v 5^{+/+}$mice, trabecular bone thickness (Figure 2A), trabecular spacing and structure model index (SMI) were increased in older mice, whereas trabecular number and connectivity density demonstrated an age-related decline (Supplementary Table 3). Trpv5 $5^{--}$mice showed similar age-related changes as $\operatorname{Trp} v 5^{+/+}$mice in the trabecular compartment although their trabecular bone thickness increased less pronounced during aging resulting in significantly lower bone mass in 52- and 78-week-old mice compared to their Trpv $5^{+/+}$littermates (Figure 2A).

Within the subtrochanteric bone compartment, an age-related decrease in cortical thickness (Figure 2B) was seen in $\operatorname{Tr} p v 5^{+/+}$mice, while a stable cortical bone volume was maintained throughout life. Consistent with these findings, we found the endocortical volume (i.e. marrow cavity volume) to be increased with aging (Figure 2C-2D). TRPV5 deficiency led to similar agerelated changes, but cortical thickness (Figure 2B) and cortical volume (Supplementary Table 3) were reduced at all ages compared to the $\operatorname{Trp} v 5^{+/+}$mice. At 78 weeks of age, both endocortical volume and cortical porosity were significantly greater in the $\operatorname{Tr} p v 5^{-/}$mice compared to their non-deficient littermates (Figures 2C and 2D, respectively). Other cortical parameters, such as moment of inertia and perimeter also increased during aging but they were not different between the genotypes (Supplementary Table 3).

\section{Mineralization of the trabecular structure is reduced in $\operatorname{Trpv5}^{-/-}$mice}

Tibial quantitative backscattered electron (qBEI) imaging showed in trabecular bone an age-related increase in the average and most abundant mineralization densities (CaMean and CaPeak, respectively) and an age-related reduction in the areas undergoing primary mineralization (CaLow) in wildtype mice (Figures 3A, 3B and 3D). The heterogeneity of mineralization (CaWidth) did not alter during aging in $\operatorname{Tr} p v 5^{+/+}$mice (Figure 3C). $\operatorname{Tr} p v 5^{-/-}$mice demonstrated age-related changes for all qBEI parameters measured being positively correlated with age for CaMean, CaPeak and CaWidth (Figures 3A, 3B and 3C, respectively), whereas CaLow was negatively correlated (Figure 3D). Both CaMean and CaPeak were reduced in the younger $\operatorname{Trp} v 5^{-/-}$mice, being significant at 52 weeks

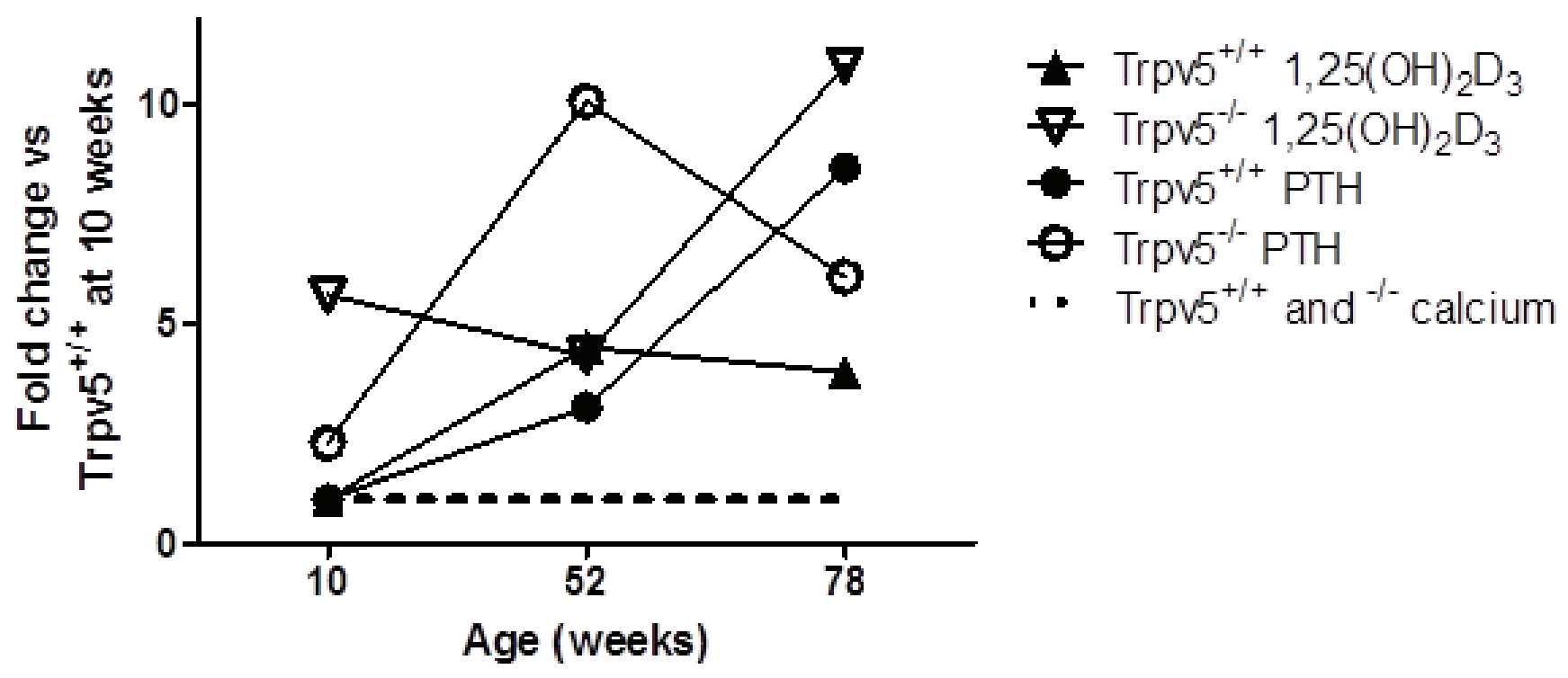

Figure 1: Trpv5 deficiency leads to elevated serum 1,25(OH) $\mathbf{D}_{3}$ and PTH levels. Depicted is an illustration of temporal changes in serum levels of hormones involved in calcium homeostasis. Based on the measured serum calcium levels in the 10 and $52-$ week old animals and calcium measured of 78-week-old male mice in this and a previous study, we have depicted calcium to be constant irrespective of age and genotype (black dotted line, not representing an actual value). Both $1,25(\mathrm{OH})_{2} \mathrm{D}_{3}$ (triangle symbols) and PTH (round symbols) levels are elevated in 10-week-old $\operatorname{Trpv} 5^{-/}$(open symbols) compared to Trpv $5^{+/+}$mice (closed symbols). In fact, the serum levels for both hormones in 10-week-old TRPV5 deficient mice are similar to those in 52-week-old $\operatorname{Trpv5^{+/+}}$ mice. The data presented are not longitudinal and hence should not be presented as a line graph but they serve solely as an illustration for temporal serum changes in mice lacking Trpv5. We emphasized this by disconnecting the lines from the actual measurements. 
and 10 weeks of age versus Trpv $5^{+/+}$mice, respectively (Figures 3A and 3B, respectively). In the metaphyseal cortical bone, all parameters changed with age in both genotypes (Supplementary Table 4). In contrast to the trabecular data, in cortical bone no difference for any of the parameters at any age was observed between the
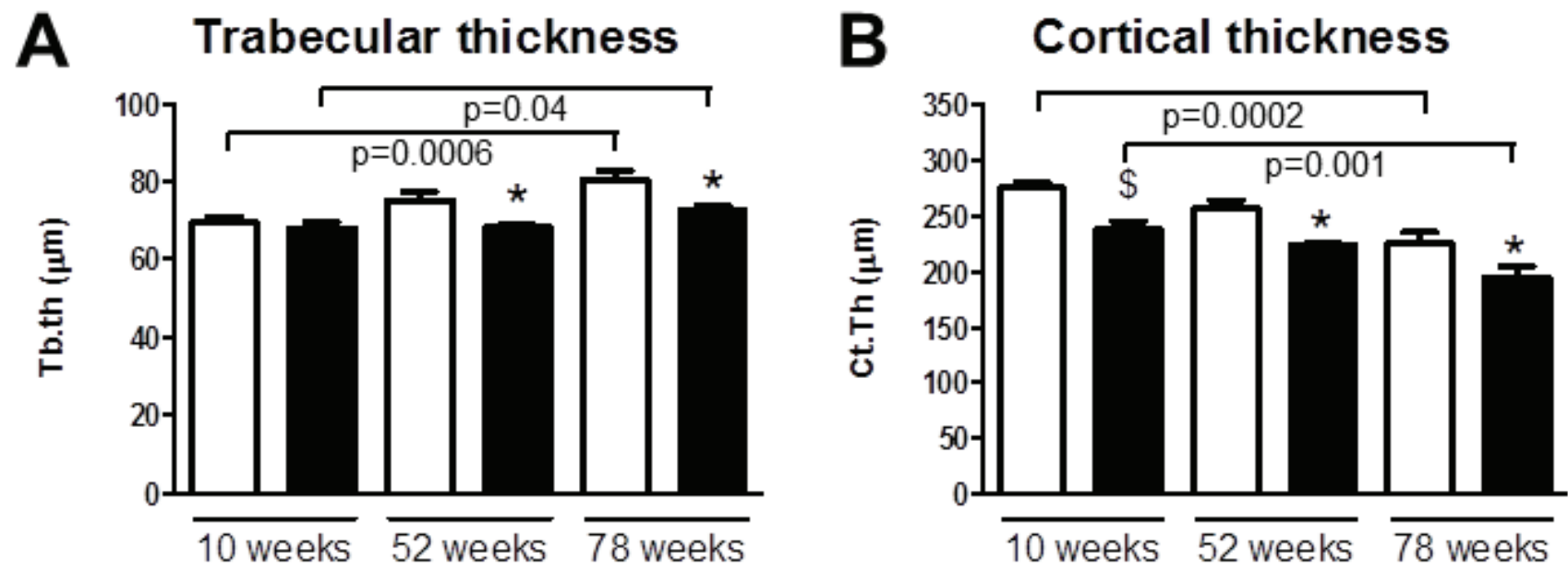

C

\section{Endocortical volume}

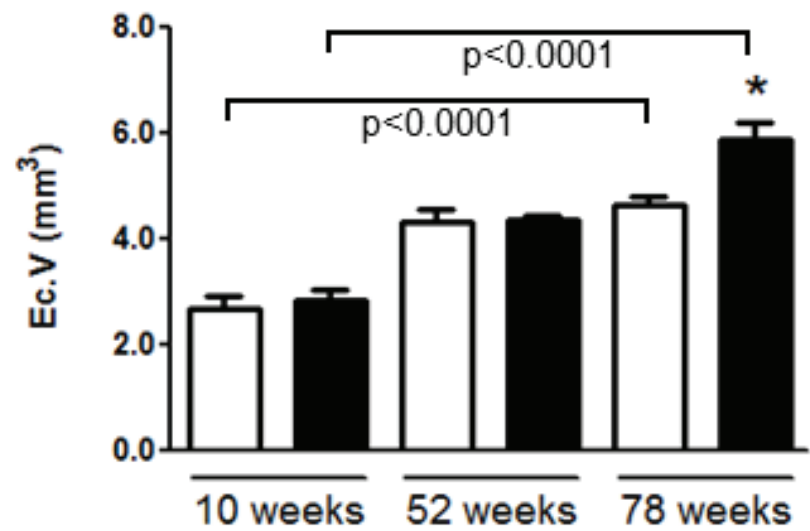

D
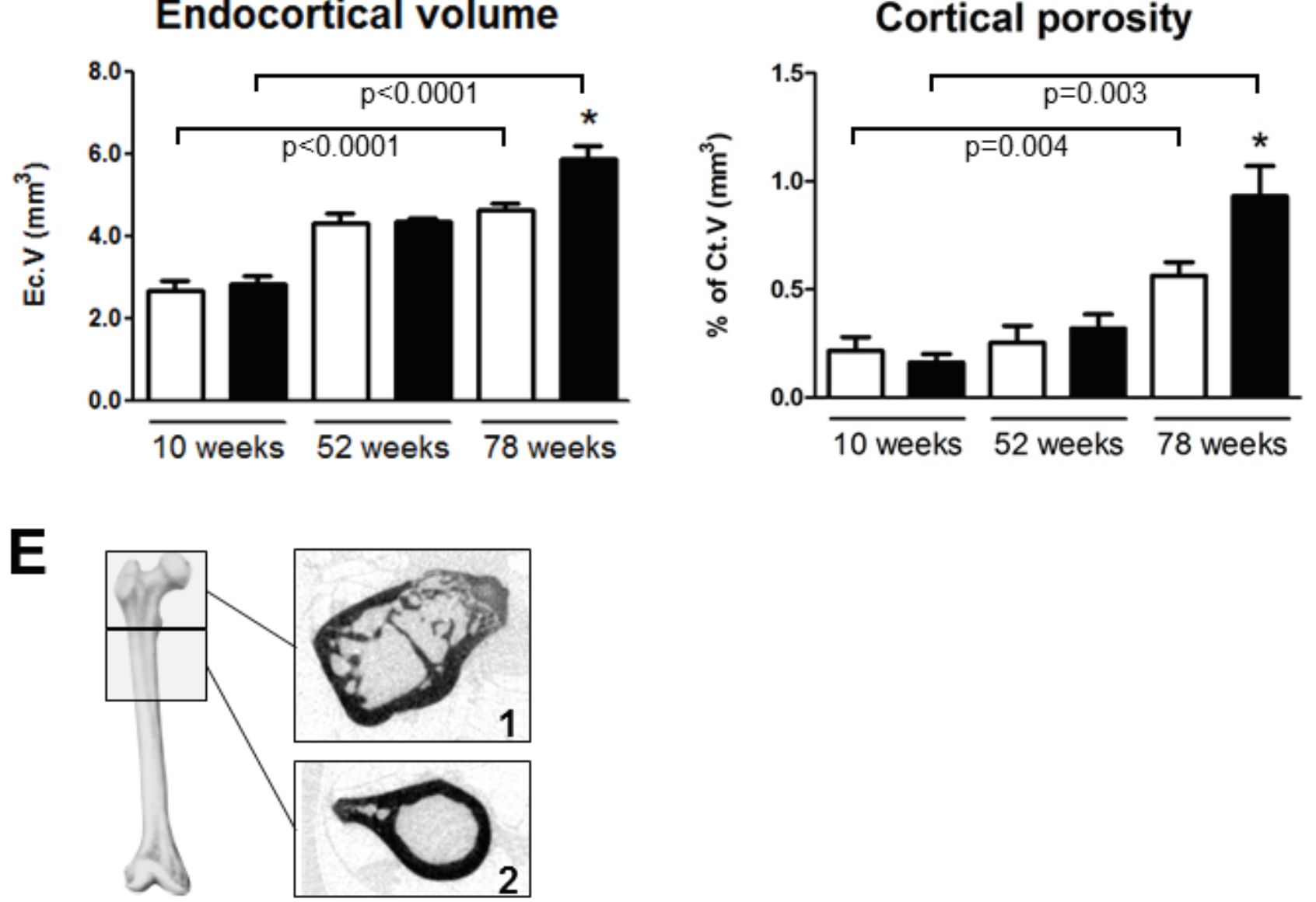

Figure 2: Trpv5 deficiency leads to reduced bone thickness. Bone microarchitectural parameters from male $\operatorname{Trpv5^{+/+}}$ (white bars) and $\operatorname{Trpv}^{-/}$(black bars) mice at 10, 52 and 78 weeks of age were determined by $\mu \mathrm{CT}$ analysis $(n=5-11)$. A. trabecular thickness in the femoral head, B. cortical thickness, C. endocortical volume and D. cortical porosity in the subtrochanteric area. E. scan regions for the calculations on trabecular (1) and cortical bone (2). Data are presented as means \pm SEM. ${ }^{*} p<0.05$ versus $\operatorname{Trpv} 5^{+/+} \cdot{ }^{\$} p<0.001 v s \operatorname{Trpv} 5^{+/+}$. Significant aging effects for a genotype are indicated by horizontal lines. 
genotypes (Supplementary Table 4). Both in Trpv5 $5^{+/+}$ and $\operatorname{Trp} 5^{-/}$mice, cortical CaMean, CaPeak and CaWidth increased with age, whereas CaLow was negatively correlated (Supplementary Table 4). In the cortices of both genotypes osteocyte lacunae number and size were assessed. No difference was found for both parameters when corrected for cortical bone area (Supplementary Figure 1).

\section{Bone resorption in $\operatorname{Trpv5}^{+/+}$and $\operatorname{Trpv5} 5^{-/-}$bones during aging}

Bone resorption as assessed by urinary DPD was similar between the $\operatorname{Trp} v 5^{+/+}$mice age groups (Figure 4A). In contrast, $\operatorname{Tr} p v 5^{-/}$mice demonstrated an age-related
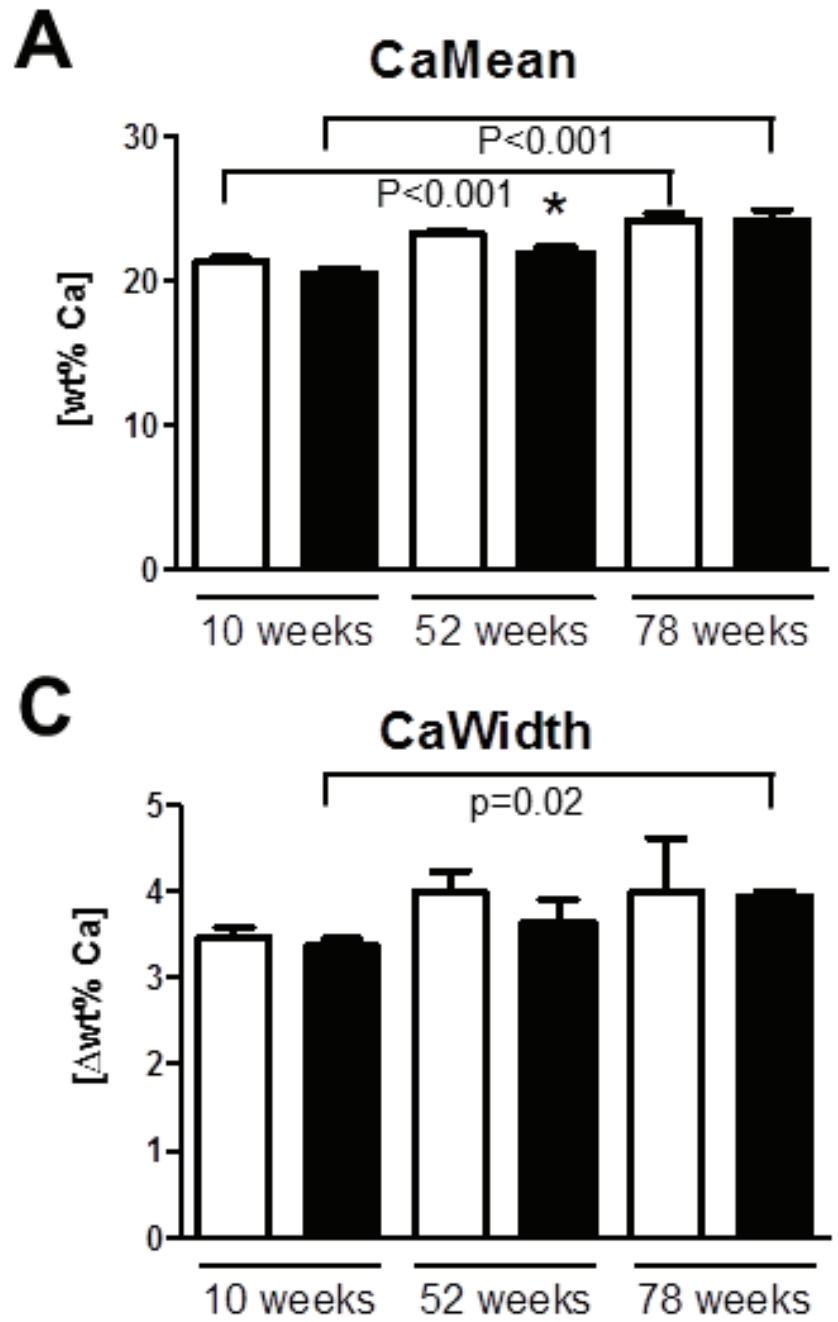

increase in DPD levels. At 10 and 52 weeks of age, Trpv5 mice had significantly lower DPD levels compared to $\operatorname{Trp} v 5^{+/+}$mice but at 78 weeks of age, these were similar in both genotypes (Figure 4A). Osteoclast numbers and surface in femoral bone sections of 78-week-old were not significantly different between genotypes (Figures $4 \mathrm{~B}$ and $4 \mathrm{C}$, respectively). In bone marrow cultures derived from 78-week-old mice, osteoclast numbers generated from $\operatorname{Trpv}^{-/}$precursor cells were significantly lower (Figure 4D), but this caused no difference in in vitro bone resorption (Figures 4E). Frequencies of bone marrow populations containing osteoclast precursors (i.e. immature blasts, myeloid blasts, and monocytes [13] as evaluated by flow cytometry were not different between $\operatorname{Trp} v 5^{+/+}$and $\operatorname{Tr} p v 5^{-/-}$mice (Supplementary Table 5). The only different cell population in the bone marrow pool was
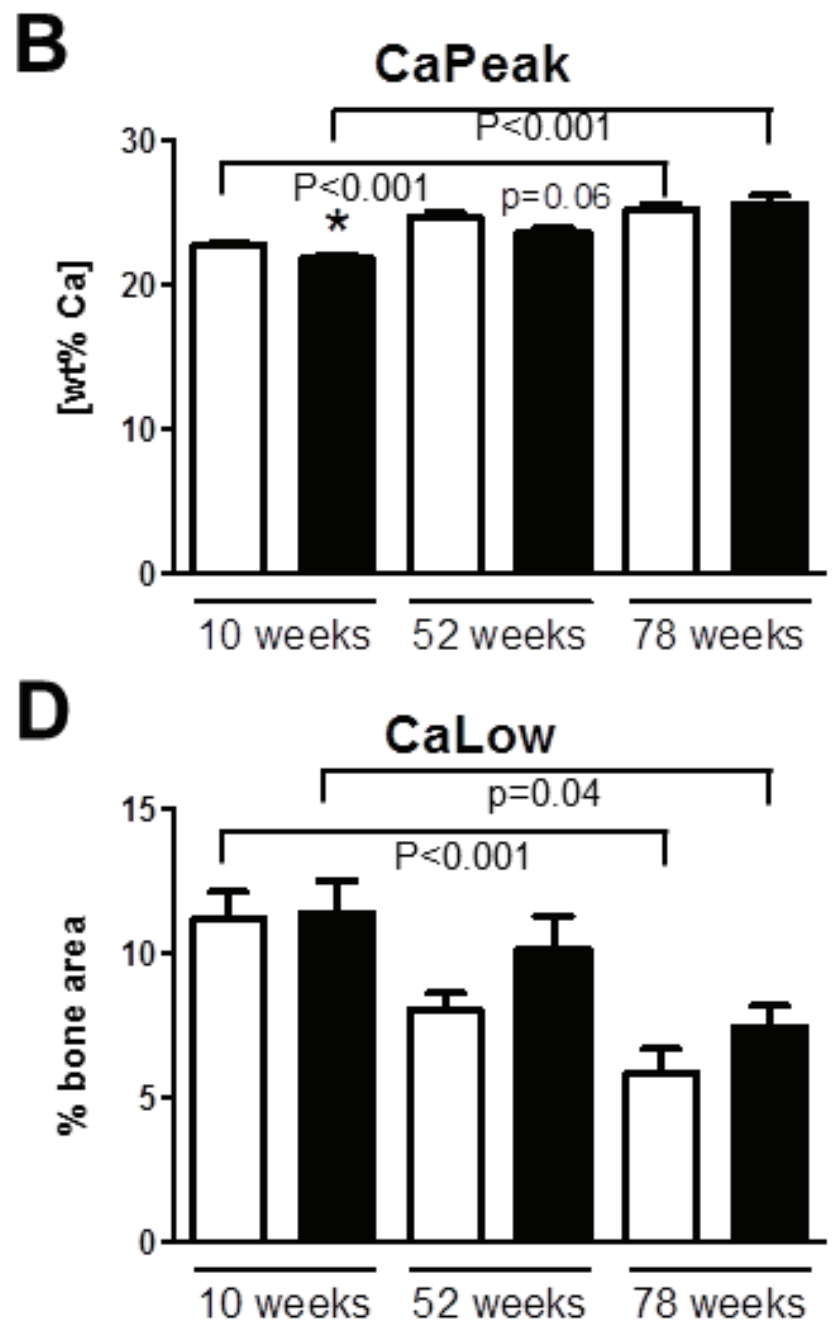

Figure 3: Bone mineralization is affected in $\operatorname{Trpv}^{-/-}$mice. Using quantitative backscattered electron imaging, the tibial BMDD was assessed from male Trpv5 $5^{+/+}$(white bars) and Trpv5 $5^{-/-}$(black bars) mice at 10, 52 and 78 weeks of age $(n=3-6)$. Parameters were measured in the metaphyseal spongious bone compartment with respect to A. CaPeak, B. CaMean, C. CaWidth (all expressed as units of $[\mathrm{wt} \% \mathrm{Ca}]$ ) and $\mathbf{D}$. CaLow (expressed as percentage bone area). Values are presented as mean $\pm \mathrm{SEM} .{ }^{*} p<0.05$ versus $\operatorname{Trpv} 5^{+/+}$. ${ }^{*} p<0.01$ vs $\operatorname{Tr} v 5^{+/+}{ }^{\$} p<0.001$ vs $\operatorname{Tr} p v 5^{+/+}$. Significant aging effects for a genotype are indicated by horizontal lines. 
A

Urinary deoxypyrydinoline

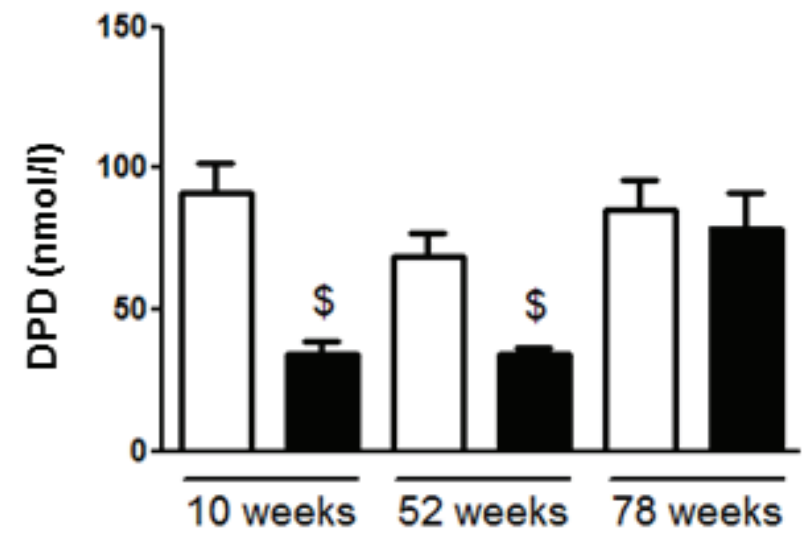

C

Osteoclast surface

- in situ -

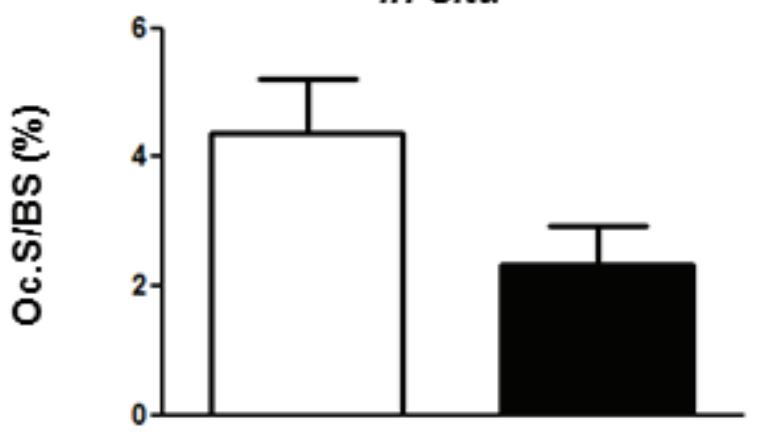

B

Osteoclast number

- in situ -

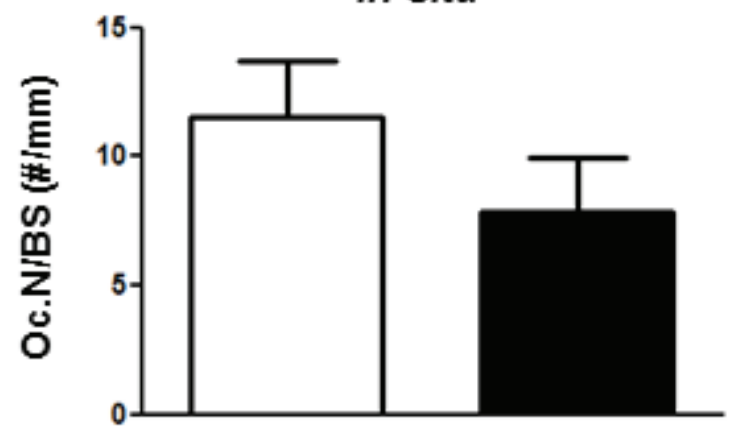

D

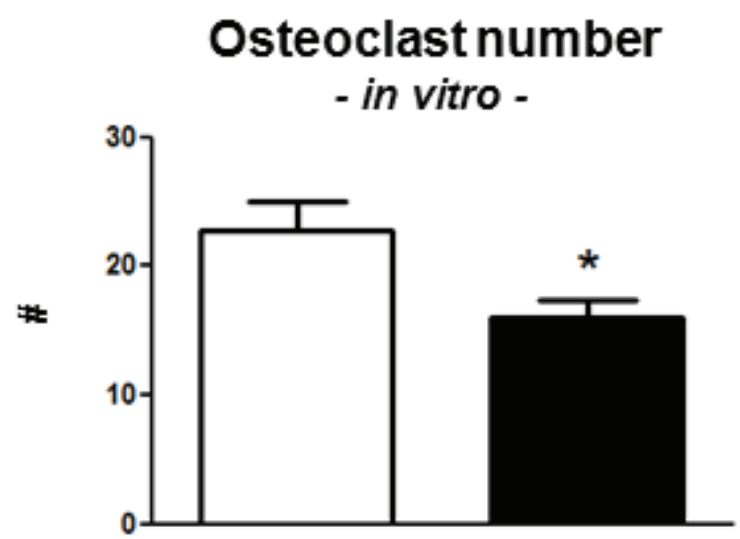

E

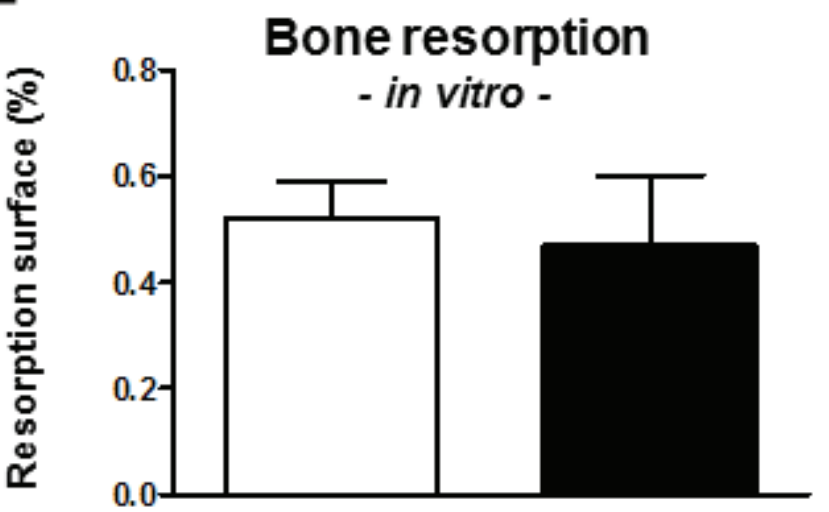

Figure 4: Bone resorption is reduced in $\operatorname{Trpv5}^{-/-}$mice until 52 weeks of age. A. Urinary DPD measurement in 10, 52 and 78-week-old male $\operatorname{Trpv5}^{+/+}$(white bars) and $\operatorname{Trpv5}^{-/}$(black bars) mice. B. osteoclast number and C. osteoclast surface per bone surface in TRAP-stained femoral bone section of 78-week-old male $\operatorname{Trpv5^{+/+}}$ and $\operatorname{Trpv5^{-/}}$ mice. D. osteoclast number and E. osteoclast surface assessed in bone marrow-derived osteoclast cultures from 78-week-old male $\operatorname{Trpv5^{+/+}}$ and $\operatorname{Tr} p v 5^{-/}$mice. Values are presented as mean \pm SEM. $* p<0.05$ versus Trpv5 ${ }^{+/+} .{ }^{\$} p<0.001$ vs Trpv5 $5^{+/+}$. 
A

Trpv6

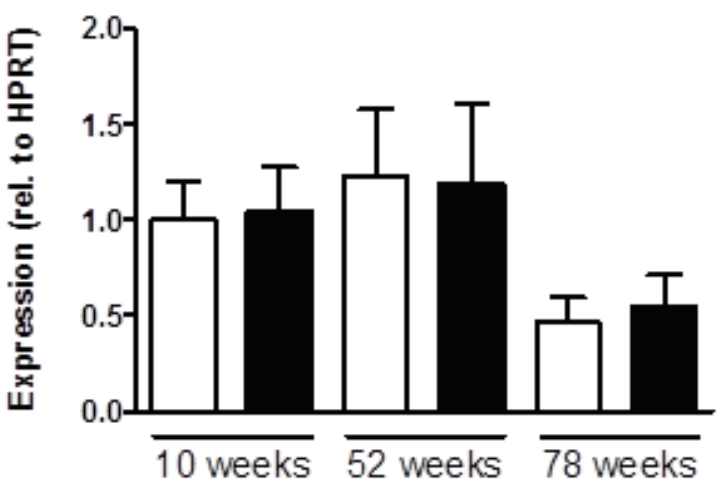

\section{Vdr}

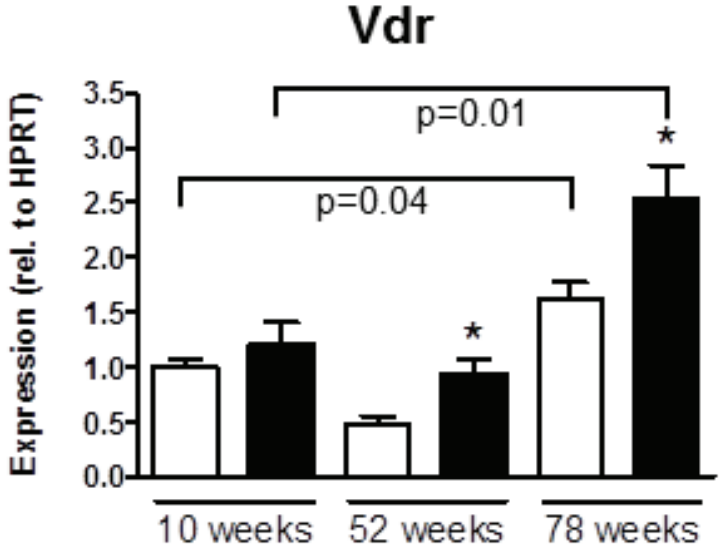

E

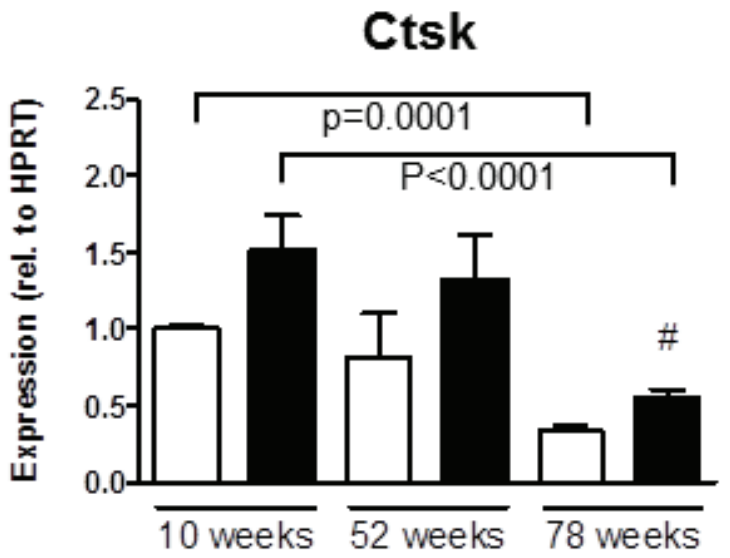

C
B

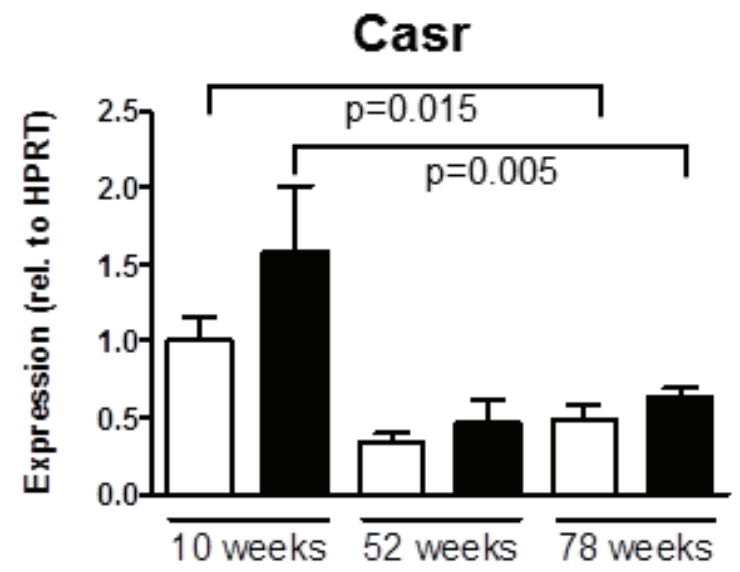

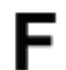

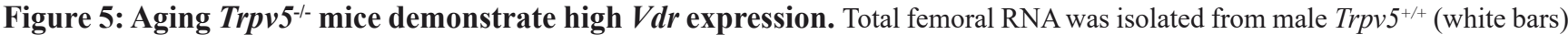
and $\operatorname{Trpv}^{-/-}$(black bars) mice at 10, 52 and 78 weeks of age $(n=3-12)$. A. Trpv6, B. Casr, C. Vdr, D. Acp5, E. Ctsk and F. Phex mRNA.

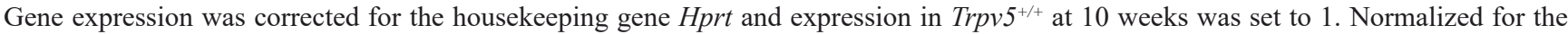
housekeeping gene Values are presented as mean \pm SEM. ${ }^{*} p<0.05$ versus $\operatorname{Tr} p v 5^{+/+}$. ${ }^{*} p<0.01 v s \operatorname{Trpv} 5^{+/+} .{ }^{\$} p<0.001 v s \operatorname{Trpv5^{+/+}}$. Significant aging effects for a genotype are indicated by horizontal lines. 
the lymphoid precursor cells, which were significantly lower in the $\operatorname{Trpv} 5^{-/}$mice at 78 weeks.

\section{Trpv5 deficiency does not affect bone strength}

Three-point-bending tests were performed on a subset of femurs from male 78-week-old Trpv5 $5^{+/+}$and Trpv5 $5^{-1}$ mice. There were no differences in maximum load, stiffness or energy of the femurs between the genotypes (Supplementary Figures 2A-2C). Moreover, Young's modulus, a measure for elasticity of the bone, was unaffected (Supplementary Figure 2D).

\section{Old Trpv5 $5^{-/}$and Trpv5 $5^{+/+}$mice show differences in femoral gene expression patterns}

Next, we generated femoral bone gene expression profiles for both genotypes at 10,52 and 78 weeks of age by focusing at genes involved in calcium transport and homeostasis, osteoclast function, bone metabolism and phosphate homeostasis.

\section{Calcium transport and homeostasis}

Trpv5 mRNA was similarly expressed in femurs of 10-, 52- and 78-week-old Trpv5 $5^{+/+}$mice (Supplementary Table 6). Trpv6 mRNA expression in femurs of Trpv $5^{+/+}$ mice was lower in the 78-week-old animals compared to younger age groups, though not significant (Figure 5A). Calcium sensing receptor (Casr) and vitamin D receptor $(V d r)$ mRNA expression were negatively and positively correlated with age in $\operatorname{Trpv5^{+/+}}$ mice, respectively (Figure $5 \mathrm{~B}$ and $5 \mathrm{C}$, respectively). Other genes involved in transcellular $\mathrm{Ca}^{2+}$ transport, i.e. calbindin- $\mathrm{D}_{9 \mathrm{~K}}(\mathrm{~S} 100 \mathrm{~g})$, sodium/calcium exchanger $1 \quad(N c x l)$ and plasma membrane calcium ATPase 1 (Atp2bl) did not change during aging of $\operatorname{Trpv5}^{+/+}$mice (Supplementary Table 6). Comparing $\operatorname{Trp} v 5^{-/}$and $\operatorname{Trp} v 5^{+/+}$mice, no significant differences were observed for any of the genes related to calcium homeostasis at any time point. Besides reduced $V d r$ expression at 52 and 78 weeks of age (Figure 5C) and increased Ncxl expression at 78 weeks of age (Supplementary Table 6).

\section{Osteoclast function}

The mRNA expression of the osteoclast marker genes for tartrate-resistant acid phosphatase (Acp5), cathepsin $\mathrm{K}(C t s k)$ and the calcitonin receptor (Ctr) was negatively correlated with age in both genotypes (Figures 5D-5E and Supplementary Table 6). All osteoclast marker genes assessed were slightly but consistently elevated in the Trpv5 $5^{-/}$compared to Trpv $5^{+/+}$mice (Figures 5D-5E and Supplementary Table 6), but only reached significance for Acp5 and Ctsk.

\section{Bone metabolism and phosphate homeostasis}

We also assessed several genes associated with bone metabolism and phosphate homeostasis. Among them, phosphate regulating endopeptidase homolog, X-linked (Phex), osteopontin (Spp1) and sclerostin (Sost)) showed reduced mRNA expression with aging in $\operatorname{Trpv} 5^{+/+}$ mice (Figure 5F and Supplementary Table 6). Ankylosis, progressive homolog (Ank), Fibroblast growth factor 23 (Fgf23) and Klotho (Kl) were not modulated in an agerelated manner in these mice (Supplementary Table 6). As for the Trpv5 $5^{+/+}$mice, Phex, Spp1 and Sost expression showed a negative correlation with age in $\operatorname{Trpv} 5^{-/}$mice (Figure 5F and Supplementary Table 5). Only Phex expression at 78 weeks of age was significantly different in $\operatorname{Trp} v 5^{-/}$mice compared to Trpv $5^{+/+}$mice (Figure 5F).

Overall, the $\operatorname{Trpv} 5^{-}$mice showed similar agerelated trends as did the Trpv $5^{+/+}$mice but for some genes significantly higher expression of bone-related genes was observed at 78 weeks of age compared to the Trpv $5^{+/+}$ mice. In bone marrow-derived osteoblasts and osteoclasts, all marker genes studied were expressed at lower levels in the Trpv $5^{-\leftarrow}$ mice, but none of these differences reached significance (Supplementary Table 7).

\section{DISCUSSION}

Trpv5 deficiency strongly stresses the $\mathrm{Ca}^{2+}$ homeostasis in order to maintain stable plasma $\mathrm{Ca}^{2+}$ levels $[3,6]$. Here, we demonstrate that mice lacking Trpv5 are able to maintain similar serum $\mathrm{Ca}^{2+}$ levels as their Trpv5expressing counterparts during aging up to at least 78 weeks of age. This is achieved by pronounced age-related increments in serum $1,25(\mathrm{OH})_{2} \mathrm{D}_{3}$ and PTH. Age-related increases of these hormones were also observed in Trpv5 - mice but interestingly at 10 weeks of age $1,25(\mathrm{OH})_{2} \mathrm{D}_{3}$ levels were already at the level of older (52 weeks) $\operatorname{Trpv5^{+/+}}$ mice, pointing to premature aging in this respect in $\operatorname{Trpv} 5^{-/}$mice. The stress on the $\mathrm{Ca}^{2+}$ homeostasis is paralleled by a reduced degree of bone mineralization and accelerated changes in bone microarchitecture as exemplified by reduced bone thickness.

\section{Normocalcemia in $\operatorname{Trpv}^{-/-}$mice is associated with elevated serum 1,25(OH) ${ }_{2} \mathrm{D}_{3}$ and PTH}

Trpv5 $5^{-/}$mice predominantly suffer from renal calcium loss, which is initially compensated by increased intestinal calcium hyperabsorption through TRPV6 followed by reduced bone mass and mineralization, to retain normocalcemia [3]. This compensatory mechanism is accompanied by elevated levels of $1,25(\mathrm{OH})_{2} \mathrm{D}_{3}$ and PTH already at 10 weeks of age. Later in life, $1,25(\mathrm{OH})_{2} \mathrm{D}_{3}$ levels further increase in $\operatorname{Tr} p v 5^{-/}$mice even to levels exceeding $1300 \mathrm{pmol} / \mathrm{l}$. These extremely high $1,25(\mathrm{OH})_{2} \mathrm{D}_{3}$ levels may explain that at 78 weeks of age 
the PTH levels in the Trpv5 $5^{-/}$are lower compared to the $\operatorname{Trp} v 5^{+/+}$mice. The continuous exposure of an organism to elevated PTH and $1,25(\mathrm{OH})_{2} \mathrm{D}_{3}$ levels has adverse consequences for the skeleton. Circulating levels of PTH rise with age in rats and humans [9, 10]. From human clinical studies, it has become apparent that prolonged exposure to high PTH (p.e. primary hyperparathyroidism) indirectly increases osteoclast activity and decreases age-related osteoblast replicative activity [14-17], both contributing to bone loss.

Elevated PTH levels during human aging are at least partially caused by a decline in vitamin D levels, which is associated with reduced calcium absorption. Vitamin D levels are associated with elevated bone mineral density and reduced risk of fracture [18]. In contrast to the anabolic vitamin D effects on the skeleton in humans, Lieben et al. showed that exposure to high $1,25(\mathrm{OH})_{2} \mathrm{D}_{3}$ levels leads to reduced bone mineralization in mice [19]. In addition, Smith and coworkers showed that chronic high vitamin $\mathrm{D}$ levels in mice lead to a decrease in cortical thickness and a decline in bone stiffness [20]. In the current study, we demonstrate upregulation of the $V d r$ gene at the level of the femoral bone and strongly elevated $1,25(\mathrm{OH})_{2} \mathrm{D}_{3}$ levels in the oldest Trpv5 $5^{-/}$age group. Although we have no data to support this, upregulation of $V d r$ expression and high serum $1,25(\mathrm{OH})_{2} \mathrm{D}_{3}$ levels would facilitate enhanced vitamin D signaling within bone. Enhanced vitamin D signaling may thus be a mechanism to limit the influx of $\mathrm{Ca}^{2+}$ into bone, which would contribute to retaining serum $\mathrm{Ca}^{2+}$ but at the expense of bone mineralization.

Another mechanism that may contribute to retaining normocalcemia is osteocytic osteolysis. Through this process, osteocytes are capable of resorbing the lacunae around them, resulting in the liberation of ions in case of a strong $\mathrm{Ca}^{2+}$ demand, such as lactation [21-23]. Suffering from a chronic negative $\mathrm{Ca}^{2+}$ balance but keeping serum levels constant, osteocytic osteolysis in Trpv5 $5^{-/}$mice may suffice to restore serum $\mathrm{Ca}^{2+}$, which in turn would cause the observed increased cortical porosity. Although minute changes in osteocyte function may have great impact due to their numbers within bone, we failed to show detectable changes in osteocytic lacunar size or number at 78 weeks of age.

\section{Mineralization of bone is affected in $\operatorname{Trpv5} 5^{-/-}$mice}

In concordance with a chronic $\mathrm{Ca}^{2+}$ insufficiency in $\operatorname{Trpv}^{-1-}$ mice are our findings on bone mineralization density. Although no effects were seen at the level of the tibial cortex, mineralization density was decreased in the trabecular bone along with non-significantly larger areas of low mineralized bone observed in the 52- and 78-week-old $\operatorname{Trp} 5^{-/-}$mice compared to $\operatorname{Tr} p v 5^{+/+}$mice. As we have shown previously, the enhanced intestinal $\mathrm{Ca}^{2+}$ uptake could not fully compensate for the renal $\mathrm{Ca}^{2+}$ loss in young $\operatorname{Trp} v 5^{--}$mice, leading to reduced skeletal mineralization [6]. Later in life, the persisting stress on $\mathrm{Ca}^{2+}$ homeostasis may have led to the observed increased undermineralization in old $\operatorname{Tr} p v 5^{-/}$mice but also to the increased endocortical osteoclast and osteocyte activity.

\section{Trpv5 deficiency accelerates bone loss}

Aging is associated with bone loss by thinning of cortical bone and loss of the trabecular network [24]. Indeed, we found a decrease in cortical thickness with aging and a reduction of the trabecular bone volume fraction and connectivity, despite increased thickness of the remaining trabecular bone. Previous studies looking at bone microarchitecture in aging mice found similar results [25-27]. Glatt et al observed an age-related decline in the trabecular bone volume fraction (BV/TV) [25], something we saw until the age of 52 weeks but not thereafter, despite a significant age trend. In line with our data, Ferguson et al. described cortical expansion by periosteal apposition in male mice to compensate for trabecular bone loss and reduced mineralization [26]. Hamrick and coworkers showed BMD loss, periosteal expansion and endosteal resorption up to 29 months of age [27]. Interestingly, a concurrent increase in endosteal apposition was observed at this age, for which no explanation was provided but it may be to counteract excessive endosteal bone loss. Nevertheless, it may provide an anabolic time-window for interventions to improve bone quantity/quality later in life. We did not observe differences in bone resorption between 10 and 78 weeks of life as measured by urinary DPD, which corresponds with the study by Hamrick, who showed increased bone resorption only after 18 months of age [27].

Trpv5 deficiency led to a more accelerated bone aging phenotype, including reduced trabecular and cortical bone mass as well as increased endocortical bone volume later in life compared to $\operatorname{Tr} p v 5^{+/+}$mice. For example, the $\operatorname{Trp} v 5^{-/}$mice have a cortical thickness at 10 weeks of age that is not reached until $\operatorname{Trpv} 5^{+/+}$at 78 weeks of age.

\section{Osteoclast number and bone resorption seems unaffected in 78-week-old Trpv5 $5^{-/-}$mice}

In contrast to our study in young mice where we found increased numbers of osteoclasts in 10-week-old $\operatorname{Trpv5^{-/}}$ mice[6], we observed no differences in osteoclast number between $\operatorname{Trp} v 5^{+/+}$and $\operatorname{Tr} p v 5^{-/}$mice, but both genotypes showed lower osteoclast formation at 78 weeks compared to 52 weeks. To explain the discrepancy between the previous and current study, we assessed whether exhaustion of osteoclast precursors could have taken place in the bone marrow. However, apart from a reduction in the number of lymphoid precursor cells, we did not find a reduction in monocyte number.

Despite having a bone resorption defect in early 
life [6] and reduced urinary DPD levels in Trpv $5^{-/-}$mice at 52 weeks, the current study showed that endocortical bone resorption in $\operatorname{Trp} v 5^{-/-}$mice exceeds that of Trpv $5^{+/+}$ mice between 52 and 78 weeks of age, resulting in an enlargement of the marrow space (endocortical volume) at the level of the subtrochanter. In line with this would be the elevated expression levels of a few osteoclast markers in femurs of 78-week-old Trpv $5^{-/}$mice. However, bone resorption was not different between the genotypes at this age, in vivo and ex vivo, as shown by DPD levels, histomorphometry and bone marrow-derived osteoclast cultures. Apparently, old Trpv5 $5^{-/}$mice seem to be able to regain their bone resorption capacity, independent of TRPV5. Perhaps, prolonged high levels of circulating $1,25(\mathrm{OH})_{2} \mathrm{D}_{3}, \mathrm{PTH}$ or another yet unknown mechanism following TRPV5 deficiency has a restorative effect at the level of osteoclast activity on the skeleton of these mice. This suggests that the reduced bone resorption caused by TRPV5 deficiency that we reported previously for mice at 10 weeks of age [6] and is apparent by the decreased DPD levels at 52 weeks, may not have been entirely intrinsic and is overcome at older age.

\section{Bone strength is not compromised in old Trpv5 -r- mice}

The combination of reduced bone mass and increased endosteal resorption suggests that life-long stress on calcium homeostasis due to TRPV5 deficiency weakens the skeleton of old mice. Besides the effects on cortical bone mass, we observed increased cortical porosity during aging but especially in the 78-weekold mice lacking TRPV5. Cortical porosity has been appreciated as an age-related phenomenon in the elderly and an important determinant of bone strength but the precise mechanism behind this process remains unclear [28]. Besides these effects on the skeleton of Trpv5 $5^{-1-}$ mice, the 3-point-bending tests yielded similar outcomes for both genotypes at 78 weeks of age. The reason for this remains obscure, but may be due to a combination of 1) changes in the composition or the organization of the extracellular matrix leading to structural changes within the skeleton that could not be assessed through 3-point bending; 2) reduced mineralization in $\operatorname{Trp} v 5^{-/}$mice that renders bone to be more flexible; 3) non-significantly increased cortical perimeter in Trpv5 $5^{-/}$mice between 52 and 78 weeks of age $\left(1.5 \mathrm{~mm}^{3}\right)$ compared to $\operatorname{Trpv} 5^{+/+}$mice $\left(1.2 \mathrm{~mm}^{3}\right)$ that may aid to counteract loss of bone strength. Finally, mice may possess a yet unknown 'compensation' mechanism that in case of bone loss protects them from a fracture, something that is rarely seen in mice.

\section{Human $\mathrm{Ca}^{2+}$ homeostasis and bone metabolism}

Several disease states, such as chronic kidney diseases and intestinal malabsorption syndromes (e.g. celiac disease, intestinal surgery, aging and vitamin D deficient nutrition) in humans cause continuous stress on the maintenance of adequate serum $\mathrm{Ca}^{2+}$ levels, and a clear relationship has been established with bone deterioration [29-32]. The phenotype of the Trpv5 $5^{-/}$mice suggests that maintenance of adequate circulatory $\mathrm{Ca}^{2+}$ in these patients should be a priority in order to prevent bone loss and increased risk fractures at older age.

In conclusion, this study demonstrates that TRPV5 is important for normal bone development and that an unfavorable $\mathrm{Ca}^{2+}$ balance persisting during aging leads to accelerated bone loss in Trpv5-deficient mice. The strongly elevated vitamin D levels in Trpv5 in restoring serum $\mathrm{Ca}^{2+}$ but at the expense of maintaining bone mass and/or mineralization in vivo. The TRPV5 deficient mouse appears to be a suitable model for lifelong challenge of calcium homeostasis and its consequences for bone metabolism.

\section{MATERIALS AND METHODS}

\section{Animals}

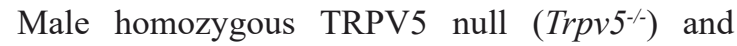
$\operatorname{Trpv} 5^{+/+}$mice were generated as described before [3]. and were fed standard chow and given water ad libitum. At the age of 10, 52 and 78 weeks, mice were sacrificed (group sizes varied between 4-12) and serum, urine and bones were collected. The animal ethics board of the Radboud University Nijmegen approved all animal experimental procedures.

\section{Analytical procedures}

Serum $\mathrm{Ca}^{2+}$ was calorimetrically determined with a $\mathrm{Ca}^{2+}$ assay kit (Sigma) according to the manufacturer's description at $595 \mathrm{~nm}$, using a Bio-Rad microplate reader (Bio-Rad) or using a home-made calcium assay as described before [33]. Serum PTH levels were measured using a mouse intact PTH ELISA kit following standard procedure (Immutopics, San Clemente, CA, USA). Serum $1,25(\mathrm{OH})_{2} \mathrm{D}_{3}$ concentrations were measured by immunoextraction followed by quantitation by ${ }^{125}$ I-RIA (IDS, Boldon, UK) [6]. Urinary total deoxypyridinoline (DPD) cross-links were determined, using the Metra DPD assay according to the guidelines (Quidel). 


\section{Microcomputed tomography $(\mu \mathrm{CT})$}

Femurs were scanned using the SkyScan 1072 microtomograph (Bruker MicroCT) with a resolution of $7 \mu \mathrm{m}$ and subsequently analyzed as described in detail before [6]. According to guidelines recently published [34] the following settings were used: X-Ray power and tube current were $40 \mathrm{kV}$ and $0.25 \mathrm{~mA}$, respectively. Beam hardening $(20 \%)$ was reduced using a $1 \mathrm{~mm}$ aluminum filter, ring-artefacts were reduced (set at 5), exposure time was 5.9 seconds and an average of three pictures was taken at each angle $\left(0.9^{\circ}\right)$ to generate final images. Using different software packages from Bruker MicroCT (NRecon, CtAn and Dataviewer), bone microarchitectural parameters were assessed in trabecular and cortical bone of all mice ( $n=14$ for both genotypes). The trabecular bone parameters trabecular tissue volume, bone volume, trabecular volume fraction (BV/TV), trabecular thickness, trabecular number, connectivity density and structure model index were determined in the femoral head (scan area $0-3.25 \mathrm{~mm}$ of proximal femur). In the subtrochanter area (scan area $3.25-6.3 \mathrm{~mm}$ from femoral head), cortical volume, cortical thickness, cortical porosity, polar moment of inertia (MOI; proxy for bone strength) and perimeter were analyzed. For image processing, trabecular bone was manually selected and cortical bone was automatically selected. We used global thresholding for segmentation, followed by applying optimized threshold levels for trabecular and cortical bone measurements.

\section{Bone mechanical properties (3-point bending)}

Femurs were stored in phosphate-buffered saline at $-20^{\circ} \mathrm{C}$ until further use. Before the 3-point bending test, femurs were scanned according to the settings mentioned above. The procedure was carried out as previously described in detail [35]. Briefly, femurs were placed in a custom made 3-point bending device, with the lower loading posts $10 \mathrm{~mm}$ apart. Mechanical testing was performed, using a Single Column Lloyd LRX System (Lloyd Instruments). Displacement $(\mathrm{mm})$ and force $(\mathrm{N})$ were registered. Using the same settings for filtration, segmentation and binarization as mentioned above in the $\mu \mathrm{CT}$ section, the MOI, reflecting the ability of the bone to withstand torsion, was calculated using $\mathrm{Ct}$ Analyzer software (Bruker MicroCT). This was determined in the $\mu \mathrm{CT}$ scan-derived cross-section that corresponded to the fracture site resulting from the bending test. From the resulting displacement to force graphs as well as the MOI values, ultimate force $(\mathrm{N})$, stiffness $(\mathrm{N} / \mathrm{mm})$, energy $(\mathrm{Nmm})$ and elastic modulus (MPa) were determined as described before [36].

\section{Quantitative backscattered electron imaging}

Dissected tibiae were routinely fixed and dehydrated in ethanol, and embedded in polymethylmethacrylate. Sample blocks were trimmed using a low speed diamond saw (Isomet-R, Buehler Ltd.). Sectioned bone surfaces were sequentially ground with sand paper with increasing grid number followed by polishing with diamond grains (size down to 1 micron) on hard polishing clothes by a precision polishing device (PM5 Logitech, Glasgow, Scotland). Finally the sample surface was carbon coated by vacuum evaporation (Agar SEM Carbon Coater) for scanning electron microscopy.

Bone mineralization density distribution (BMDD) was determined in the metaphyseal spongiosa and in the midshaft cortical bone by qBEI using a digital scanning electron microscope (DSM 962, Zeiss) equipped with a four-quadrant semiconductor backscattered electron detector as extensively described before [37, 38]. The accelerating voltage of the electron beam was set to 20 $\mathrm{kV}$, the probe current to $110 \mathrm{pA}$, and the working distance to $15 \mathrm{~mm}$. The cancellous and cortical bone areas were imaged at 200x nominal magnification (corresponding to a pixel resolution of $1 \mu \mathrm{m} /$ pixel. From these digital images, grey level histograms were deduced, displaying the percentage of bone area occupied by pixels of a certain gray level. The transformation of these into calcium weight percent (wt $\% \mathrm{Ca}$ ) histograms led to a bin width of $0.17 \mathrm{wt} \% \mathrm{Ca}$. A technical precision of $0.3 \%$ was achieved. The BMDD parameters like the mean (weighted mean) CaMean and most frequently occurring calcium concentration CaPeak (peak position of the BMDD) in the sample, the width of the distribution CaWidth (full width at half maximum; $\Delta \mathrm{wt} \% \mathrm{Ca}$ ) reflecting the heterogeneity in matrix mineralization and CaLow, the percentage of bone below $17.68 \mathrm{wt} \% \mathrm{Ca}$ (primary mineralization)[39].

\section{Osteocyte density measurements}

qBEI Images of cortical bone (nominal magnification 200X) with $1 \mu \mathrm{m}$ pixel resolution were used to determine osteocyte lacunae number. The mean size was evaluated from the $2 \mathrm{D}$ images of the lacunae as well as the percentage of the sectioned bone surface occupied by these lacunae (density). This was done, using the software package Bioquant (Version 7.20; Bioquant image analysis corporation).

\section{Bone histomorphometry}

After excision, femurs were routinely embedded in methylmetacrylate as described before [6]. Six $\mu \mathrm{m}$ sections were subjected to tartrate-resistant acid phosphatase (TRAP) staining. Sections were deacrylated, hydrated and 
rinsed in $0.2 \mathrm{M}$ sodium acetate / $50 \mathrm{mM}$ tartaric acid for 5 minutes. Naphtol AS-MX $(0.5 \mathrm{mg} / \mathrm{ml})$ and $1.1 \mathrm{mg} / \mathrm{ml}$ Fast red TR salt (both from Sigma) were added and incubated for 120 minutes at $37^{\circ} \mathrm{C}$. Counterstaining was performed with haematoxylin for 5 seconds and after air-drying, the sections were embedded in Permount (Thermo Fischer Scientific). Images were taken with a Nikon Eclipse E400 system (Nikon, Lijnden, the Netherlands) and osteoclast number (Oc.N) and surface (Oc.S) were determined per total bone surface (BS), using Bioquant software.

\section{Bone marrow cultures}

Bone marrow cells derived from 78-week-old mice stimulated towards osteoclasts and osteoblasts were cultured as described in detail [6, 40]. After 6 days of osteoclast culture, TRAP and coomassie brilliant blue stainings were used to stain for osteoclasts and resorption pits on bone slices left behind by osteoclasts, respectively [6]. Osteoclast number and resorption surface were determined and resorption surface per osteoclast was calculated, using the freely available ImageJ software (version 1.41; http://rsbweb.nih.gov/ij/). Osteoblast at day 14 were washed with PBS and taken up in TriZol for isolation of total RNA as described below.

\section{Flowcytometric analysis}

Frequencies of bone marrow populations containing osteoclast precursors were determined by flowcytometry, essentially as described in de Vries et al. [13]. Bone marrow cells from approximately 10- and 22-monthold mice were collected, washed and counted. All immunofluorescent labelings and washes took place in FACS buffer (PBS containing 1\% BSA). Bone marrow cell suspensions were spun down at $1500 \mathrm{rpm}$ for $5 \mathrm{~min}$ at $4^{\circ} \mathrm{C}$ ) and incubated for $30 \mathrm{~min}$ in $25 \mu \mathrm{l}$ per $10^{6}$ cells biotinylated ER-MP12, recognizing CD31 [41]. Cells were washed once and incubated in $25 \mu \mathrm{l}$ per $10^{6}$ cells FACSbuffer containing FITC-conjugated ER-MP20, recognizing Ly6C [41], and streptavidine-phycoerythrin (PE; Becton Dickinson; $10 \mu \mathrm{l}$ per $10^{6}$ cells) for $30 \mathrm{~min}$. Finally, cells were fixed in 1\% vol/vol paraformaldehyde in PBS for 15 min, washed and taken up in PBS. Cells were analyzed using a BD FACS Calibur and data were processed using Diva software (Becton Dickinson).

\section{RNA isolation, cDNA synthesis and real-time PCR}

Pulverized material from mouse femurs (including bone marrow) was resuspended in Trizol Reagent (Gibco). RNA isolation, cDNA synthesis and real-time PCR on these femur samples as well as on the samples from the bone marrow cultures were performed as described previously [42]. Primer and probe sequences and concentrations used for real-time PCR are listed in Supplementary Table 1. The gene hypoxanthine-guanine phosphoribosyl transferase (HPRT) was used as an internal control to normalize for differences in RNA extraction and degradation as well as for efficiency of the cDNA synthesis. Data were presented as relative mRNA levels calculated by the equation $2^{-\Delta \mathrm{Ct}}(\Delta \mathrm{Ct}$ (cycle threshold $)=\mathrm{Ct}$ of gene of interest minus $\mathrm{Ct}$ of housekeeping gene).

\section{Statistics}

In all experiments values are expressed as mean \pm SEM unless stated otherwise. Differences between genotypes were tested for significance by AN(C)OVA and adjusted for age. In the in vivo studies, regression analyses were performed to assess age-related changes. Two-way ANOVA was performed to assess for interaction between age and genotype. Values were considered significantly different at $p<0.05$.

\section{ACKNOWLEDGMENTS}

We are grateful to P. Kramer, L. Ndamba and B. de Hoon (Internal Medicine, Erasmus MC, Rotterdam, the Netherlands) and A. van Oudenaren (Immunology) for technical assistance. This work was supported by grants of the Dutch Organization of Scientific Research (Zon-Mw 902.18.298, 916.26.21, and (NWO)-Research Institute for Diseases in the Elderly (Grant 948-00-001).

\section{CONFLICTS OF INTEREST}

The authors declare no conflicts of interest.

\section{GRANTS}

(NWO)-Research Institute for Diseases in the Elderly (Grant 948-00-001)

\section{REFERENCES}

1. Bronner F. Calcium absorption - a paradigm for mineral absorption. J Nutr. 1998; 128:917-920.

2. Hoenderop JG, Nilius B and Bindels RJ. Calcium absorption across epithelia. Physiol Rev. 2005; 85:373-422.

3. Hoenderop JG, van Leeuwen JP, van der Eerden BC, Kersten FF, van der Kemp AW, Merillat AM, Waarsing JH, Rossier BC, Vallon V, Hummler E and Bindels RJ. Renal $\mathrm{Ca} 2+$ wasting, hyperabsorption, and reduced bone thickness in mice lacking TRPV5. J Clin Invest. 2003; 112:19061914. 
4. Renkema KY, Nijenhuis T, van der Eerden BC, van der Kemp AW, Weinans H, van Leeuwen JP, Bindels RJ and Hoenderop JG. Hypervitaminosis D mediates compensatory Ca2+ hyperabsorption in TRPV5 knockout mice. J Am Soc Nephrol. 2005; 16:3188-3195.

5. Nijenhuis T, van der Eerden BC, Zugel U, Steinmeyer A, Weinans H, Hoenderop JG, van Leeuwen JP and Bindels RJ. The novel vitamin D analog ZK191784 as an intestinespecific vitamin D antagonist. FASEB J. 2006; 20:21712173.

6. van der Eerden BC, Hoenderop JG, de Vries TJ, Schoenmaker T, Buurman CJ, Uitterlinden AG, Pols HA, Bindels RJ and van Leeuwen JP. The epithelial Ca2+ channel TRPV5 is essential for proper osteoclastic bone resorption. Proc Natl Acad Sci U S A. 2005; 102:1750717512.

7. Orwoll ES and Meier DE. Alterations in calcium, vitamin $\mathrm{D}$, and parathyroid hormone physiology in normal men with aging: relationship to the development of senile osteopenia. J Clin Endocrinol Metab. 1986; 63:1262-1269.

8. Perry HM, 3rd, Horowitz M, Morley JE, Fleming S, Jensen J, Caccione P, Miller DK, Kaiser FE and Sundarum M. Aging and bone metabolism in African American and Caucasian women. J Clin Endocrinol Metab. 1996; 81:1108-1117.

9. Chapuy MC, Durr F and Chapuy P. Age-related changes in parathyroid hormone and 25 hydroxycholecalciferol levels. J Gerontol. 1983; 38:19-22.

10. Armbrecht HJ, Forte LR and Halloran BP. Effect of age and dietary calcium on renal 25(OH)D metabolism, serum 1,25(OH)2D, and PTH. Am J Physiol. 1984; 246:E266-270.

11. Sambrook P and Cooper C. Osteoporosis. Lancet. 2006; 367:2010-2018.

12. van Abel M, Huybers S, Hoenderop JG, van der Kemp AW, van Leeuwen JP and Bindels RJ. Age-dependent alterations in Ca2+ homeostasis: role of TRPV5 and TRPV6. Am J Physiol Renal Physiol. 2006; 291:F1177-1183.

13. de Vries TJ, Schoenmaker T, Hooibrink B, Leenen PJ and Everts V. Myeloid blasts are the mouse bone marrow cells prone to differentiate into osteoclasts. J Leukoc Biol. 2009; 85:919-927.

14. Klompmaker TR. Lifetime high calcium intake increases osteoporotic fracture risk in old age. Med Hypotheses. 2005; 65:552-558.

15. Vestergaard $P$ and Mosekilde L. Fractures in patients with primary hyperparathyroidism: nationwide follow-up study of 1201 patients. World J Surg. 2003; 27:343-349.

16. Saleem TF, Horwith M and Stack BC, Jr. Significance of primary hyperparathyroidism in the management of osteoporosis. Otolaryngol Clin North Am. 2004; 37:751761, viii-ix.

17. Di Monaco M, Vallero F, Di Monaco R, Mautino F and Cavanna A. Primary hyperparathyroidism in elderly patients with hip fracture. J Bone Miner Metab. 2004; 22:491-495.
18. Suda $\mathrm{T}$, Takahashi $\mathrm{F}$ and Takahashi N. Bone effects of vitamin $\mathrm{D}$ - Discrepancies between in vivo and in vitro studies. Arch Biochem Biophys. 2012; 523:22-29.

19. Lieben L, Masuyama R, Torrekens S, Van Looveren R, Schrooten J, Baatsen P, Lafage-Proust MH, Dresselaers T, Feng JQ, Bonewald LF, Meyer MB, Pike JW, Bouillon R, et al. Normocalcemia is maintained in mice under conditions of calcium malabsorption by vitamin D-induced inhibition of bone mineralization. J Clin Invest. 2012; 122:1803-1815.

20. Smith EA, Frankenburg EP, Goldstein SA, Koshizuka K, Elstner E, Said J, Kubota T, Uskokovic M and Koeffler HP. Effects of long-term administration of vitamin D3 analogs to mice. J Endocrinol. 2000; 165:163-172.

21. Teti A and Zallone A. Do osteocytes contribute to bone mineral homeostasis? Osteocytic osteolysis revisited. Bone. 2009; 44:11-16.

22. Bonewald LF. The amazing osteocyte. J Bone Miner Res. 2011; 26:229-238.

23. Qing H, Ardeshirpour L, Pajevic PD, Dusevich V, Jahn K, Kato S, Wysolmerski J and Bonewald LF. Demonstration of osteocytic perilacunar/canalicular remodeling in mice during lactation. J Bone Miner Res. 2012; 27:1018-1029.

24. Vanderschueren D, Laurent MR, Claessens F, Gielen E, Lagerquist MK, Vandenput L, Borjesson AE and Ohlsson C. Sex steroid actions in male bone. Endocr Rev. 2014; 35:906-960.

25. Glatt V, Canalis E, Stadmeyer L and Bouxsein ML. Agerelated changes in trabecular architecture differ in female and male C57BL/6J mice. J Bone Miner Res. 2007; 22:1197-1207.

26. Ferguson VL, Ayers RA, Bateman TA and Simske SJ. Bone development and age-related bone loss in male C57BL/6 J mice. Bone. 2003; 33:387-398.

27. Hamrick MW, Ding KH, Pennington C, Chao YJ, Wu YD, Howard B, Immel D, Borlongan C, McNeil PL, Bollag WB, Curl WW, Yu J and Isales CM. Age-related loss of muscle mass and bone strength in mice is associated with a decline in physical activity and serum leptin. Bone. 2006; 39:845853.

28. Zebaze RM, Ghasem-Zadeh A, Bohte A, Iuliano-Burns S, Mirams M, Price RI, Mackie EJ and Seeman E. Intracortical remodelling and porosity in the distal radius and postmortem femurs of women: a cross-sectional study. Lancet. 2010; 375:1729-1736.

29. Suzuki H and Kondo K. Chronic kidney disease in postmenopausal women. Hypertens Res. 2012; 35:142-147.

30. Larussa T, Suraci E, Nazionale I, Abenavoli L, Imeneo $\mathrm{M}$ and Luzza F. Bone mineralization in celiac disease. Gastroenterol Res Pract. 2012; 2012:198025.

31. Casagrande DS, Repetto G, Mottin CC, Shah J, Pietrobon $\mathrm{R}$, Worni $\mathrm{M}$ and Schaan BD. Changes in bone mineral density in women following 1-year gastric bypass surgery. Obes Surg. 2012; 22:1287-1292.

32. Christakos S, Dhawan P, Porta A, Mady LJ and Seth T. 
Vitamin D and intestinal calcium absorption. Mol Cell Endocrinol. 2011; 347:25-29.

33. van Driel M, Koedam M, Buurman CJ, Roelse M, Weyts F, Chiba H, Uitterlinden AG, Pols HA and van Leeuwen JP. Evidence that both 1alpha,25-dihydroxyvitamin D3 and 24-hydroxylated D3 enhance human osteoblast differentiation and mineralization. J Cell Biochem. 2006; 99:922-935.

34. Bouxsein ML, Boyd SK, Christiansen BA, Guldberg RE, Jepsen KJ and Muller R. Guidelines for assessment of bone microstructure in rodents using micro-computed tomography. J Bone Miner Res. 2010; 25:1468-1486.

35. Erlebacher A and Derynck R. Increased expression of TGF-beta 2 in osteoblasts results in an osteoporosis-like phenotype. J Cell Biol. 1996; 132:195-210.

36. Gruber HE. Adaptations of Goldner's Masson trichrome stain for the study of undecalcified plastic embedded bone. Biotech Histochem. 1992; 67:30-34.

37. Fratzl-Zelman N, Morello R, Lee B, Rauch F, Glorieux FH, Misof BM, Klaushofer K and Roschger P. CRTAP deficiency leads to abnormally high bone matrix mineralization in a murine model and in children with osteogenesis imperfecta type VII. Bone. 2010; 46:820-826.
38. Roschger P, Fratzl P, Eschberger J and Klaushofer K. Validation of quantitative backscattered electron imaging for the measurement of mineral density distribution in human bone biopsies. Bone. 1998; 23:319-326.

39. Roschger P, Paschalis EP, Fratzl P and Klaushofer K. Bone mineralization density distribution in health and disease. Bone. 2008; 42:456-466.

40. de Vries TJ, Schoenmaker T, Beertsen W, van der Neut R and Everts V. Effect of CD44 deficiency on in vitro and in vivo osteoclast formation. J Cell Biochem. 2005; 94:954966.

41. de Bruijn MF, Slieker WA, van der Loo JC, Voerman JS, van Ewijk W and Leenen PJ. Distinct mouse bone marrow macrophage precursors identified by differential expression of ER-MP12 and ER-MP20 antigens. Eur J Immunol. 1994; 24:2279-2284.

42. Eijken M, Hewison M, Cooper MS, de Jong FH, Chiba H, Stewart PM, Uitterlinden AG, Pols HA and van Leeuwen JP. 11beta-Hydroxysteroid dehydrogenase expression and glucocorticoid synthesis are directed by a molecular switch during osteoblast differentiation. Mol Endocrinol. 2005; 19:621-631. 